\title{
Complaints of neurotic patients that are of interest for a cardiologist
}

\author{
Jerzy A. Sobański ${ }^{1}$, Katarzyna Klasa ${ }^{2}$, Lech Popiołek ${ }^{1}$, Krzysztof Rutkowski ${ }^{1}$, Edyta Dembińska ${ }^{1}$, \\ Michał Mielimąka ${ }^{1}$, Katarzyna Cyranka ${ }^{1}$, Łukasz Müldner-Nieckowski ${ }^{1}$, Bogna Smiatek-Mazgaj ${ }^{1}$, \\ Paweł Rodziński \\ ${ }^{1}$ Chair of Psychotherapy, Jagiellonian University Medical College, Cracow, Poland \\ ${ }^{2}$ Department of Psychotherapy, University Hospital, Cracow, Poland \\ ${ }^{3}$ Clinical Unit, Department of Adult, Adolescent, and Paediatric Psychiatry, University Hospital, Cracow, Poland
}

\begin{abstract}
A bstract
Background: Patients in various areas of medicine report symptoms that are unexplained by other medical reasons than psychological/psychiatric. Some of them urgently seek treatment due to cardiovascular complaints, mostly rapid heart rate, palpitations and chest pain. Typical cardiac investigations, usually showing no organic reasons for these conditions, bring little information about stressful life events and psychological predispositions of these patients. Identification of coexistence of "cardiac" symptoms with other symptoms typical for neurotic disorders and difficult life circumstances may facilitate not only psychiatric diagnosis but also evaluation by cardiologists, primary care physicians, and other specialists.
\end{abstract}

Aim: To determine the psychosocial context of psychogenic "pseudocardiac" symptoms and their coexistence with other symptoms in patients with neurotic disorders.

Methods: Medical records of patients from the years 1980-2002 that included self-administered questionnaires transformed into an anonymised database were examined. An analysis of the relationship between symptoms reported in the Symptom Checklist and biographical circumstances described in the Life Inventory before admission to a psychotherapy day clinic for patients with neurotic disorders was performed using simple logistic regression with estimation of odds ratios and their $95 \%$ confidence intervals.

Results: The symptoms of tachycardia/palpitations and chest pain were very common, present in most subjects, and were significantly associated with such circumstances as suboptimal conflict solving by passive aggression or quarrels, uncertainty in the relationship, a sense of being inferior to the partner, and poor financial situation. In addition, these "pseudocardiac" symptoms were also associated with such childhood reminiscences as origin from a large low income family, feeling that the family of origin was inferior to others, and experience of parental hostility or lack of support.

Conclusions: Physicians of all specialties who deal with patients experiencing pseudocardiac symptoms should expect their psychological background and perform a simple interview to identify the presence of adverse biographical circumstances described above. Identification and discussing these difficult experiences with the patients may help to convince them to seek psychological support or psychotherapy.

Key words: medically unexplained symptoms, frequent complaints, psychogenic tachycardia, psychogenic chest pain, psychocardiology

Kardiol Pol 2015; 73, 11: 1114-1121

\section{INTRODUCTION}

Symptoms of neurotic disorders are very common and their subjectively perceived severity results in frequent visits to primary care physicians and other specialists associated by patients with the predominant complaints [1]. Obviously, cardiology is no exception among those areas of medicine that

Address for correspondence:

Jerzy A. Sobański, MD, Chair of Psychotherapy, Jagiellonian University Medical College, ul. Lenartowicza 14, 31-138 Kraków, Poland, e-mail: molocko@poczta.fm Received: 29.01.2015 Accepted: 24.03.2015 Available as AoP: 14.05.2015 
provide help to numerous frequent attenders. Patients with psychogenic complaints imitating cardiac problems feel neglected, erroneously considered healthy, and inappropriately declined help. However, their need for appropriate diagnosis and treatment, but also understanding by cardiologists is warranted [2]. This situation is also bothersome for physicians who fail to effectively convince the patients that their symptoms are psychogenic [3, 4].

"Pseudocardiac" complaints are among the most worrisome symptoms leading to acute patient responses (call for ambulance, presentation to an emergency room). Symptoms of coronary artery disease and myocardial infarction are well known and metaphorically projected to difficult situations, threatening events, and associated strong emotions (e.g. "I thought I would have an infarct", "my company has collapsed", "broken heart", "blow straight to the heart", "my heart has broken", "I had my heart in my throat"). These symptoms may also symbolise positive feelings ("a voice is calling inside my heart", "It warmed my heart", "my heart jumped", etc.).

Formally, pseudocardiac symptoms may be categorised as somatoform disorders (in particular, when related to disturbed autonomic cardiovascular control), phobias (agoraphobia, social phobia, and specific phobias), and other anxiety disorders (panic disorder, generalised anxiety disorder, depressive disorders, and mixed anxiety disorders, etc. [1, 5]). The autonomic component of anxiety, abnormalities of adrenergic transmission (interestingly, related to anger misrepresentation processes [6]), somatosensory amplification [7], and disorders of interoception [1] are associated with sensitisation and increased susceptibility of the cardiovascular system to the symptoms of palpitation, sinus tachycardia, and chest pain (which may even result in turn in "real" cardiovascular problems [8]). The strength of these emotions, motivating patients to seek help, and their "cardiac inadequacy" are illustrated in some patients by often negative results of advanced cardiac investigations (ranging from electrocardiography and echocardiography, with respective stress tests based on these modalities, to cardiac magnetic resonance imaging and invasive coronary angiography. Another typical phenomenon are well-known associations of cardiac complaints with stressful life events and problems with interpersonal relation, public appearances and evaluation, and sexual life (not necessarily due to a cardiovascular risk [9]). These associations are obviously multidirectional and include depression and depressive reactions, but also severe cardiovascular problems [7, 10-12]. In response to these issue, we have witnessed development of psychocardiology [13], suggestions for psychiatric consultations, the presence of a clinical psychologist in cardiology and cardiac surgery units, prescribing psychoactive drug therapy etc. It also useful for non-psychiatrist physicians to associate patient personal events and circumstances with symptoms (e.g., $[14,15])$. Among patients with non-cardiac chest pain, immigrant status, work problems (in men) and problems with home/family relations (in women) are reported two to three times more frequently compared to other patients [16, 17].

The most common pseudocardiac symptoms include palpitations, tachycardia, and chest pain with concomitant anxiety disorders (particularly panic disorder), worrying, depressive mood, and neurotic disorders [18-20]. Non-cardiac chest pain occurs in a large proportion of patients (about one third of the general population) [18, 19]. Not surprisingly, panic attacks occur in about $25-50 \%$ of patients with chest pain $[5,20]$ but it is surprising that this problem continues to be diagnosed late [3, 4]. Diagnostic search for triggers of cardiac symptoms among life events is based on the assumption that each stress increases the risk of cardiac arrhythmia due to increased sympathetic stimulation, and stress and arrhythmias exacerbate each other [8]. Patients with "pseudocardiac" problems are characterised by disturbed role models and more frequent physician visits due to uncertainties regarding the cause of their symptoms [7]. Significant variability and heterogeneity of symptoms accompanying "cardiac" problems usually hinder and delay the diagnosis [3, 4], and also disturb communication with patients. One of the common errors is informing patients that they are healthy instead of directing history to psychologic problems which would reduce focus on somatic complaint, improve patient-physician communication, and facilitate appropriate referral for further treatment. As patients seen by cardiologists (similarly to other non-psychiatrist physicians) are usually reluctant to accept a psychogenic background of their pseudocardiac symptoms and suggestions of psychotherapy [2], exploration of stressful life events and their association with psychosomatic symptoms may be equally important for the diagnostic process as excluding their somatic causes. Such explorations are meant to be encouraged for by the present work.

The aim of the study was to evaluate associations of tachycardia/palpitation and chest pain reported by patients attending psychotherapy day clinic for neurotic disorders with stressful life events and other symptoms of neurotic disorders.

\section{METHODS}

The source of information regarding patient life events and biographical circumstances was the Life Inventory administered routinely in 1980-2002 before admission to a psychotherapy day clinic. Patient evaluation included psychiatric and psychologic examination with tests to exclude, among others, affective, schizophrenic and pseudoneurotic disorders, and severe somatic disorders [21]. Information regarding the presence and severity of symptoms were obtained from $\mathrm{KO}^{\prime} \mathrm{O}^{\prime}$ symptom checklists by J.W. Aleksandrowicz [14, 15]. Most of the 3929 studied subjects had the diagnosis of a neurotic disorder or a personality disorder and a neurotic disorder (Table 1) which was also confirmed during 3-month therapy in the day clinic. Diagnoses made before introduction of the 
Table 1. Severity of neurotic symptoms, diagnosis by ICD-10, and sociodemographic characteristics of the study subjects

\begin{tabular}{lcc|} 
& $\begin{array}{c}\text { Women } \\
\text { (n = 2582) }\end{array}$ & $\begin{array}{c}\text { Men } \\
\text { (n = 1347) }\end{array}$ \\
\hline $\begin{array}{l}\text { Overall symptom severity: } \\
\text { mean } \pm \text { SD (median) }\end{array}$ & $394 \pm 152$ & $349 \pm 151$ \\
Principal diagnosis: & $(387)$ & $(336)$ \\
F44/45 Dissociative and & $29 \%$ & \\
somatoform disorders & & $25 \%$ \\
F60 Personality disorders & $23 \%$ & $29 \%$ \\
F40/F41 Anxiety disorders & $17 \%$ & $16 \%$ \\
F48 Neurasthenia & $7 \%$ & $14 \%$ \\
F34 Dysthymia & $7 \%$ & $5 \%$ \\
F50 Eating disorders & $5 \%$ & $0 \%$ \\
F42 Obsessive-compul- & $2 \%$ & $2 \%$ \\
sive disorder & & \\
F43 Reaction to stress & $1 \%$ & $2 \%$ \\
and adjustment disorders & & $70 \%$ \\
Other & $3 \%$ & $30 \%$ \\
No data & $6 \%$ & $6 \%$ \\
Age: mean \pm SD (median) & $33 \pm 9(33)$ & $32 \pm 9(28)$ \\
Education: & & \\
No/primary & $9 \%$ & $12 \%$ \\
Secondary (including & $57 \%$ & $56 \%$ \\
university students) & & \\
Higher & $34 \%$ & \\
Employed & $59 \%$ & \\
Unemployed: & $41 \%$ & \\
Pensioners & $10 \%$ & \\
University students & $23 \%$ & \\
\hline
\end{tabular}

ICD-10 classification were recategorised based on an analysis of the equivalence of clinical syndromes, and in some cases based on archived medical records, which only allowed using less precise diagnoses (e.g., F42) or just groups of diagnoses (e.g., F40 and F41) [14]. Patient consent was obtained for using data collected during routine diagnostic tests that were stored and analysed in an anonymised form. Odds ratios (OR) for concomitant presence of life circumstances and symptoms were estimated by logistic regression [14, 15] using a licensed copy of the STATISTICA PL package (Table 1).

\section{RESULTS}

The prevalence of palpitation and chest pain in the study group was high, as these symptoms were present in about three thirds of subjects regardless of their gender. Severe palpitations were reported by one third of women and one fourth of men, while severe chest pain was somewhat less frequent, with its occurrence in the preceding week reported by several per cent of subjects (Table 2).

Both symptoms of tachycardia/palpitation and pain in the heart area were reported significantly more frequently by women, with similar differences seen for most bothersome symptoms (Table 2). Symptoms that most frequently accompanied palpitation/tachycardia were feelings of tension and dyspnoea, and pain in the heart area. Other frequent concomitant symptoms were associated with agoraphobia in women and hypochondriac observation of one's own body in both genders (Table 3).

In addition to tachycardia, symptoms that most commonly accompanied cardiac pain included myalgia and wandering aches, observation of one's bodily function, feeling of a severe disease, and in men also symptoms of conversion motor paresis and fainting (Table 4).

Data shown in Tables 5-8 describe the strongest and significant associations between stressful life events with the analysed pseudocardiac complaints. Tachycardia was found to be related to childhood and adolescence events only in men, including separation from the mother before 5 years of age, reminiscence of the mother attacking the patients, and bossing around peers in the school period (Table 5).

Among adult life events, tachycardia/palpitations in women were found to be related to a divorce, marriage before 19 years of age, a feeling of being dominated by the partner, or a feeling of partner indifference. In men, tachycardia/palpitations were associated with a feeling of inferiority compared to the female partner, alcohol abuse by the female partner, feelings of paucity, and difficulties during military service (Table 6).

In women, cardiac pain was found to be associated with a reminiscence of the family being inferior to others, persecuted, low income or large, and hostility by a parent (also when being sick in childhood). In men, cardiac pain was also associated with persecuted and large families, father's impulsiveness, predominant influence of a grandmother, school problems, and premature sexual initiation (Table 7).

Table 2. Prevalence of tachycardia and pain in the heart area

\begin{tabular}{|c|c|c|c|c|}
\hline & \multicolumn{2}{|c|}{ Women $(n=2582)$} & \multicolumn{2}{|c|}{ Men $(n=1347)$} \\
\hline & Prevalence & Maximum severity & Prevalence & Maximum severity \\
\hline Tachycardia/palpitation & $80 \% * *$ & $33 \% * *$ & $74 \% * *$ & $26 \% * *$ \\
\hline Pain in the heart area & $63 \% *$ & $16 \% *$ & $59 \% *$ & $13 \% *$ \\
\hline
\end{tabular}

${ }^{*} p<0.05,{ }^{* *} p<0.001$, test for two structure indices 
Table 3. Neurotic symptoms most associated with tachycardia in women and men

\begin{tabular}{lll} 
Tachycardia/palpitations & \multicolumn{1}{c}{ Women } & \multicolumn{1}{c}{ Men } \\
\hline Feeling of tension & $5.73^{*}(3.86 ; 8.50)$ & $6.81^{*}(3.79 ; 12.27)<1>$ \\
Breathlessness, dyspnoea & $5.16^{*}(4.18 ; 6.37)$ & $4.97^{*}(3.78 ; 6.54)<2>$ \\
Pain in the heart area & $4.86^{*}(3.96 ; 5.98)$ & $4.58^{*}(3.53 ; 5.95)<4>$ \\
Muscle tremor & $4.48^{*}(3.66 ; 5.48)$ & $4.20^{*}(3.25 ; 5.43)<7>$ \\
Dizziness & $4.24^{*}(3.47 ; 5.19)$ & $4.34^{*}(3.34 ; 5.63)<6>$ \\
Anxiety in open spaces & $3.96^{*}(2.94 ; 5.33)$ & $4.62^{*}(3.53 ; 6.04)<3>$ \\
Excessive sweating & & $4.55^{*}(3.50 ; 5.92)<5>$ \\
Hot flashes & $3.89^{*}(3.16 ; 4.80)$ & $3.80^{*}(3.07 ; 4.71)$ \\
Continuous observation of bodily functions (pulse, digestion, etc.) & & \\
\hline
\end{tabular}

${ }^{*} p<0.001$, numbers $<1>$ etc. indicate ranking of associations in men; symptoms with significant odds ratio values $>3.5$ were selected

Table 4. Neurotic symptoms associated with pain in the heart area in women and men

\begin{tabular}{|lll|}
\hline Pain in the heart area & \multicolumn{1}{c}{ Women } & Men \\
\hline Muscle aches, e.g. back pain etc. & $5.03^{*}(4.23 ; 5.98)$ & $4.47^{*}(3.54 ; 5.65)<3>$ \\
Tachycardia & $4.86^{*}(3.96 ; 5.98)$ & $4.58^{*}(3.53 ; 5.95)<1>$ \\
Breathlessness, dyspnoea & $4.27^{*}(3.60 ; 5.06)$ & $4.48^{*}(3.55 ; 5.65)<2>$ \\
Unspecified, "wandering" pain & $4.12^{*}(3.47 ; 4.90)$ & $4.23^{*}(3.33 ; 5.37)<4>$ \\
Continuous observation of bodily functions (pulse, digestion, etc.) & $3.33^{*}(2.82 ; 3.94)$ & $4.23^{*}(3.35 ; 5.33)<5>$ \\
Identifying symptoms of various diseases in oneself & & $3.88^{*}(3.07 ; 4.91)<7>$ \\
Belief of severe somatic disease & & $3.73^{*}(2.96 ; 4.69)<9>$ \\
Hot flashes & & $3.68^{*}(2.92 ; 4.62)<10>$ \\
Temporary arm or leg paresis & & $3.86^{*}(2.75 ; 5.42)<8>$ \\
Fainting & & $4.18^{*}(2.78 ; 6.28)<6>$ \\
\hline
\end{tabular}

${ }^{*} p<0.001$, numbers $<1>$ etc. indicate ranking of associations in men; symptoms with significant odds ratio values $>3.5$ were selected

Table 5. Childhood and adolescence biographical circumstances associated with palpitations/tachycardia — family of origin, education

\begin{tabular}{|lcc|}
\hline Tachycardia/palpitations & Women & Men \\
\hline Separation from the mother before 5 years of age & NS & $2.02^{*}(1.02 ; 4.01)$ \\
Mother aggressive when in trouble during childhood & NS & $1.81^{* *}(1.27 ; 2.59)$ \\
Usually bossed around others in school & NS & $1.58^{*}(1.02 ; 2.44)$ \\
\hline
\end{tabular}

${ }^{*} p<0.05,{ }^{* *} p<0.001$, answers with significant odds ratio values $>1.5$ were selected

Table 6. Adult biographical circumstances associated with palpitations/tachycardia — relationship, work

\begin{tabular}{|lcc|}
\hline Tachycardia/palpitations & Women & Men \\
\hline Divorced & $1.50^{*}(1.02 ; 2.20)$ & $1.73^{*}(1.02 ; 2.96)$ \\
First (or the only) marriage before 19 years of age & $1.60^{* *}(1.20 ; 2.14)$ & $1.52^{*}(1.01 ; 2.28)$ \\
Partner usually in charge of the relationship matters & $1.51^{*}(1.01 ; 2.25)$ & $2.33^{*}(1.22 ; 4.45)$ \\
Feels inferior, weaker than the partner & & $\underline{2.96^{*}}$ \\
Thinks the partner is completely indifferent to him/her & Not applicable & $3.58^{* * *}(1.78 ; 7.19)$ \\
Partner drinks alcohol often, at every occasion & & \\
Military service with numerous problems (conflicts, punishments) & & \\
Very poor financial situation recently & & \\
\hline
\end{tabular}

${ }^{*} p<0.05,{ }^{* *} p<0.01,{ }^{* *} p<0.001$, answers with significant odds ratio values $>1.5$ were selected 
Table 7. Childhood and adolescence biographical circumstances associated with pain in the heart area — family of origin, education

\begin{tabular}{lcc|} 
Pain in the heart area & \multicolumn{1}{c}{ Women } & Men \\
\hline Family of origin was thought to be inferior & $1.79^{* * *}(1.27 ; 2.52)$ & $3.19^{*}(1.07 ; 9.50)$ \\
Family of origin was persecuted & $2.30^{*}(1.14 ; 4.63)$ & $1.53^{* * *}(1.25 ; 1.86)$ \\
Financial situation worse than that of peers & $1.77^{* *}(1.15 ; 2.71)$ & $2.21^{* *}(1.25 ; 3.94)$ \\
Five siblings & $2.33^{* * *}(1.56 ; 3.49)$ & $1.62^{*}(1.02 ; 2.57)$ \\
Six or more siblings & $2.28^{*}(1.04 ; 4.98)$ & $1.90^{*}(1.08 ; 3.36)$ \\
Mother's age $\leq 20$ years at the time the patient was born & & $1.59^{*}(1.07 ; 2.35)$ \\
Father's age $\leq 20$ years at the time the patient was born & $1.54^{*}(1.06 ; 2.23)$ & $2.27^{* *}(1.20 ; 4.28)$ \\
In childhood most influenced by a grandmother & & $1.77^{*}(1.14 ; 2.75)$ \\
As a child, usually experienced mother hostility & $1.66^{* *}(1.13 ; 2.44)$ & \\
As a child, usually experienced father hostility & & \\
Father thought to be impulsive & & \\
Father showed anger during illnesses in childhood & & \\
Grade retention & & \\
First sexual intercourse at the age of $14-16$ years & & \\
\hline
\end{tabular}

${ }^{*} p<0.05,{ }^{* *} p<0.01,{ }^{* * *} p<0.001$, answers with significant odds ratio values $>1.5$ were selected

Table 8. Adult biographical circumstances associated with pain in the heart area — relationship, work

\begin{tabular}{|c|c|c|}
\hline Pain in the heart area & Women & Men \\
\hline Widowed & $2.64^{* *}(1.37 ; 5.11)$ & \\
\hline First marriage before 19 years of age & $2.06^{* * *}(1.34 ; 3.16)$ & \\
\hline First marriage at the age of 19-20 years & $1.58^{* * *}(1.21 ; 2.08)$ & \\
\hline Very poor financial situation recently & $1.52^{* *}(1.13 ; 2.05)$ & \\
\hline Marriage arranged mostly on habitual grounds & $1.81 *(1.10 ; 2.98)$ & \\
\hline Uncertainty about the relationship, thoughts of separation & $1.52 *(1.04 ; 2.23)$ & \\
\hline Partner usually in charge of the relationship matters & & $3.30 *(0.94 ; 11.55)$ \\
\hline Things go rather wrong with the partner & $1.61 * * *(1.26 ; 2.05)$ & \\
\hline Partner drinks alcohol often, at every occasion & $1.80^{* *}(1.21 ; 2.67$ & \\
\hline Feeling of indifference towards the partner & $1.87^{* *}(1.25 ; 2.81)$ & \\
\hline Feels aversion to the partner & $1.56^{* *}(1.13 ; 2.15)$ & \\
\hline Thinks the partner is completely indifferent to him/her & $1.52^{* *}(1.11 ; 2.09)$ & \\
\hline $\begin{array}{l}\text { Taking offence and not talking to each other when in conflict } \\
\text { with the partner }\end{array}$ & $1.54^{* * *}(1.20 ; 1.99)$ & $2.08^{* * *}(1.44 ; 3.00)$ \\
\hline Police interventions during quarrels with the partner & & $2.73^{*}(1.10 ; 6.75)$ \\
\hline Military service with numerous problems (conflicts, punishments) & Not applicable & $2.59 *(1.17 ; 5.71)$ \\
\hline
\end{tabular}

${ }^{*} p<0.05,{ }^{* *} p<0.01,{ }^{* *} p<0.001$, answers with significant odds ratio values $>1.5$ were selected

Among adult factors, cardiac pain in women was associated with widowhood, early marriage, marriage arranged mostly on habitual grounds, uncertainty about the relationship and thoughts of separation, a feeling of partner indifference, aversion to the partner, alcohol abuse by the partner, and problems with communication with the partner ("quiet days"). In men, these factors included a feeling that someone else is in charge of the relationship, problems with communication with the partner, police interventions during family quarrels, and difficulties during military service (Table 8).

\section{DISCUSSION}

The aim of the present study was to evaluate the presence of pseudocardiac symptoms reported by patients investigated in a unit specialising in the treatment of neurotic disorders who were cardiologically healthy, mostly young adults [21]. 
To allow better understanding of the context of their "cardiac complaints", other symptoms and life events (both current and past) were also evaluated. Of note, pseudocardiac symptoms were highly prevalent in the study group despite the fact that somatic disease had been excluded based on physician examinations and specialist consultations. The prevalence of the evaluated symptoms was higher in woman, which may be explained by their heightened contact with bodily feelings and increased tendency to communicate them. Our findings indicate clear association of pseudocardiac symptoms with other neurotic symptoms. For palpitations, this clinical context mostly includes components of the panic anxiety disorder (dyspnoea, tension) and hypochondria symptoms. In contrast, chest pain seems to be associated with somewhat different clinical context, i.e. other pain symptoms (in addition to hypochondria symptoms). These pattern of symptom concomitance are generally in agreement with the cited literature data (e.g. $[1,5,18-20])$. An analysis of the reported life events and circumstances indicates an association of cardiac pain with abandonment experience in childhood and perhaps with the fear of separation (sometimes considered to be associated with panic anxiety), and also with parent hostility or lack of partner support in the adult life, as also indicated by study findings of other authors [2,3]. Palpitations in women seem to be more strongly associated with current relationship status and the history of its development, either early or dysfunctionally motivated (which also suggests associations with separation issues, family problems and symbols of sexual desire), while in men these associations mostly include financial situation and power and competition issues (these findings are also in agreement with the cited literature data $[16,17])$. In both genders, pain in the heart area was associated with disturbed communication, either anger inhibition in conflict situations ("quiet days"), similarly to observations by Alvarenga et al. [6], or quarrels. When childhood reminiscences were analysed, pain in the heart area in both genders was found to be associated with persecution or a lower status of the family of origin, parental threats instead of support, and in men also with school problems and premature sexual initiation. Explaining the mechanisms of responses to stress and traumatic experiences is beyond the scope of the current paper but theories of defence mechanisms and the sense of coherence [12] should be mentioned, along with recent analyses of the effect of persecution trauma on long-term health status of the victims [22-24].

The authors interpret these findings with caution, as these mostly indicate statistical associations which should be verified in the clinical perspective. The ORs for these associations were often low (in the range of 1.5-2.0 with $p$ values between 0.01 and 0.05$)$, which only indicated an increased likelihood of a possible association or a possible effect (when interpreted clinically and statistically). This is not surprising, considering a very complex, multifactorial pathogenesis of neurotic symptoms. In addition, these findings do not exclude other variables that have not been identified in the present study such as, first of all, the current way of experiencing these issues by the patient.

Our findings seem important, as pseudocardiac symptoms are often misdiagnosed [25], and a significant but neglected component of psychogenic complaints may be present even in patients with ischaemic heart disease [9, 26].

The present study, based on routine questionnaires administered to patients managed in a psychotherapy unit, has some limitations regarding generalisability of our findings but on the other hand, it offers significant practical opportunities to uncover associations using tools similar to clinical and psychological history taking focused on stressful life events. Study limitations also include reminiscence disruptions and distortions that were also reported for the psychological context (anger, stress) of triggers or acute coronary events [27].

Our study confirmed a high prevalence of pseudocardiac symptoms in neurotic patients and associations of these symptoms with other neurotic symptoms. A similar pattern of symptoms and their associations may be thus expected to be present in patients presenting to primary care physicians and cardiology outpatient clinics who are frequently burdened with neurotic disorders, and also in the general population, in which the prevalence of neurotic disorders has been estimated at as much as $30 \%$. Taking into account frequent occurrence of these disorders and their associations with life events and personality profile, more extensive psychological support and psychotherapy should be recommended for many patients seen by cardiologists [13]. Help suggested for patients with psychogenic pseudocardiac symptoms may range from explanation and assurance to intensive individualised psychotherapy, while anxiolytic drugs are less indicated in the authors' opinion (although their use has many proponents, similarly to use of safer, modern antidepressants). Examples of effective therapeutic strategies in such cases include psychodynamic approach to work on separation conflicts and abandonment and isolation situations that trigger symptoms [2, 3], and cognitive approach to work on mechanisms of copying with anger that is associated with noradrenergic disturbances [6] or analogies between panic and anger attacks. Broader information useful for the diagnosis and treatment may be provided by an analysis of the cumulative effects of life events on patient functioning [28] and numerous more sophisticated methodological solutions available [14, 15]. In summary, psychogenic cardiac symptoms such as chest pain and palpitations and tachycardia remain a diagnostic problem in non-psychiatric practice [1]. The underlying problems of neurotic disorders, anxiety, and depression are usually uncovered only during psychological evaluation (which delays optimal treatment), Thus, it is particularly useful for a physician to diagnose these mental problems based on simple history taking in the context of good, cooperative physician-patient relationship [3]. 


\section{CONCLUSIONS}

1. The symptoms of palpitations/tachycardia and pain in the heart area are very common in the population of patients with neurotic disorders and associated personality disorders. Their presence cannot be explained by the somatic condition of the patients and they are a part of the spectrum of the neurotic disorder.

2. In women, palpitations are most strongly associated with the feelings of tension, dyspnea, chest pain, muscle tremor, and dizziness, and in men also with observation of the bodily functions.

3. The symptom of pain in the heart area in women is most strongly associated with muscle aches, palpitations, dyspnoea, unspecified "wandering" pain, continuous observation of bodily functions, and anxiety, and in men also with fainting.

4. Among many life events and circumstances, the following were found to be associated with pseudocardiac symptoms: suboptimal conflict solving by passive aggression or quarrels, uncertainty in the relationship, a sense of being inferior to the partner, poor financial situation, origin from a large low income family, feeling that the family of origin was inferior to others, experience of parental hostility or lack of support.

5. Identification of the above circumstances and stressful events helps approach problems with coping with stressful experiences that are present also in non-psychiatric patients when they report pseudocardiac symptoms, and advice such interventions as psychological support and psychotherapy.

\section{Conflict of interest: none declared}

\section{References}

1. Hadlandsmyth K, Rosenbaum DL, Craft JM et al. Health care utilisation in patients with non-cardiac chest pain: a longitudinal analysis of chest pain, anxiety and interoceptive fear. Psychology Health, 2013; 28: 849-861. doi: 10.1080/08870446.2012.762100.

2. Mayou RA, Bass CM, Bryant BM. Management of non-cardiac chest pain: from research to clinical practice. Heart (British Cardiac Society). 1999; 81: 387-392.

3. Langkafel M, Senf W. Diagnosis of functional cardiac complaints from the psychosomatic view. Herz, 1999; 24: 107-113.

4. Grabhorn R, Jordan J. Functional heart symptoms. Herz, 2004; 29: 589-594.

5. Hocaoglu C, Gulec MY, Durmus I. Psychiatric comorbidity in patients with chest pain without a cardiac etiology. Isr J Psychiatry Releted Sc, 2008; 45: 49-54.

6. Alvarenga ME, Richards JC, Lambert G, Esler MD. Psychophysiological mechanisms in panic disorder: A correlative analysis of noradrenaline spillover, neuronal noradrenaline reuptake, power spectral analysis of heart rate variability, and psychological variables. Psychosomatic Med, 2006; 68: 8-16.

7. Barsky AJ Cleary PD, Coeytaux RR, Ruskin JN. The clinical course of palpitations in medical outpatients. Arch Int Med, 1995; 155: 1782-1788.
8. Siepmann M, Kirch W. Psychosomatic aspects of cardiac arrhythmias. Med Klin, 2010; 105: 479-484.

9. Puchalski B, Szymański F, Kowalik R, Filipiak KJ. Dysfunkcje seksualne u mężczyzn w ciągu pierwszych 9 miesięcy po przebytym zawale serca. Psychiatr Pol, 2013; 47: 811-826.

10. Piwoński J, Piwońska A, Sygnowska E. Is there any association between depressive symptoms and coronary artery disease in the Polish adult population. Kardiol Pol, 2014; 72: 52-55. doi: 10.5603/KP.a2013.0149

11. Pietrzyk E, Gorczyca-Michta I, Michta K et al. Depresja u chorych po pomostowaniu aortalno-wieńcowym. Psychiatr Pol, 2014; 48: 987-996.

12. Piegza M, Badura-Brzoza K et al. Poczucie koherencji w grupie kobiet poddanych koronarografii. Psychiatr Pol, 2014; 48: 975-986.

13. Halaris A. Psychocardiology: mowing toward a new subspecialty. Future Cardiol, 2013; 9: 1-6.

14. Sobański JA, Klasa K, Müldner-Nieckowski $€$ et al. Seksualne wydarzenia urazowe a obraz zaburzeń nerwicowych. Objawy związane i niezwiązane z seksualnością. Psychiatr Pol, 2013; 47: 411-431.

15. Sobański JA, Klasa K, Rutkowski Ket al. Zapamiętane postawy rodziców pacjenta a obraz zaburzeń nerwicowych. Objawy związane i niezwiązane z seksualnością. Psychiatr Pol 2013; 47: 827-851.

16. Janson Fagring A, Kjellgren KI, Rosengren A et al. Depression, anxiety, stress, social interaction and health-related quality of life in men and women with unexplained chest pain. BMC Public Health, 2008; 8: 165. doi: 10.1186/1471-2458-8-165.

17. Jerlock M, Kjellgren KI, Gaston-Johansson F et al. Psychosocial profile in men and women with unexplained chest pain. J Int Med, 2008; 264: 265-274.

18. Eslick GD, Jones MP, Talley NJ. Non-cardiac chest pain: prevalence, risk factors, impact and consulting: a population-based study. Alimentary Pharmacol Therap, 2003; 17: 1115-1124.

19. Smeijers L, van de Pas H, Nyklicek I et al. The independent association of anxiety with non-cardiac chest pain. Psychology Health, 2014; 29: 253-263. doi: 10.1080/08870446.2013.843681.

20. Fleet RP, Dupuis G, Marchand A et al. Panic disorder in emergency department chest pain patients: prevalence, comorbidity, suicidal ideation, and physician recognition. Am J Med, 1996; 101: 371-380.

21. Sobański JA, Klasa K, Rutkowski K et al. Kwalifikacja do intensywnej psychoterapii w dziennym oddziale leczenia nerwic. Psych Psychoter, 2011; 7: 20-34.

22. Walczewska J, Rutkowski K, Wizner B et al. Stiffness of large arteries and cardiovascular risk in patients with post-traumatic stress disorder. Eur Heart J, 2011; 32: 730-736.

23. Rutkowski K, Dembińska E, Walczewska J. Post-trauma symptoms in Poles persecuted for political reason, 1939-1968. J Loss Trauma (Online), 2013; doi: 10.1080/15325024.2013.824307.

24. Walczewska J, Rutkowski K, Cwynar M et al. Comprehensive geriatric evaluation in former Siberian deportees with post-traumatic stress disorder (PTSD). Am J Geriatr Psychiatr, 2014; 22: 820-828.

25. Wertli MM, Ruchti KB, Steurer J, Held U. Diagnostic indicators of non-cardiovascular chest pain: a systematic review and meta-analysis. BMC Med, 2013; 11: 239. doi: 10.1186/1741-7015-11-239.

26. Kroemeke A. Dynamika objawów depresji po zawale serca: znaczenie zmian w poziomie nadziei. Psychiatr Pol, 2013; 47: 799-810.

27. Strike PC, Steptoe A. Behavioral and emotional triggers of acute coronary syndromes: A systematic review and critique. Psychosom Med, 2005; 67: 179-186.

28. Sobański JA, Klasa K, Cyranka K et al. Wpływ kumulacji urazów seksualnych na życie seksualne i związek pacjenta. Psychiatr Pol, 2014; 48: 739-758.

Cite this article as: Sobański JA, Klasa K, Popiołek L et al. Complaints of neurotic patients that are of interest for a cardiologist. Kardiol Pol, 2015; 73: 1114-1121. doi: 10.5603/KP.a2015.0099. 


\title{
Skargi pacjentów z zaburzeniami nerwicowymi interesujące kardiologa
}

\author{
Jerzy A. Sobański ${ }^{1}$, Katarzyna Klasa ${ }^{2}$, Lech Popiołek ${ }^{1}$, Krzysztof Rutkowski ${ }^{1}$, Edyta Dembińska ${ }^{1}$, Michał \\ Mielimąka ${ }^{1}$, Katarzyna Cyranka ${ }^{1}$, Łukasz Müldner-Nieckowski ${ }^{1}$, Bogna Smiatek-Mazgaj ${ }^{1}$, Paweł Rodziński ${ }^{3}$ \\ 'Katedra Psychoterapii, Collegium Medicum, Uniwersytet Jagielloński, Kraków \\ 2Zakład Psychoterapii, Szpital Uniwersytecki, Kraków \\ ${ }^{3}$ Oddział Kliniczny, Klinika Psychiatrii Dorosłych, Dzieci i Młodzieży, Szpital Uniwersytecki, Kraków
}

\section{Streszczen ie}

Wstęp: Pacjenci pozostający pod opieką lekarzy wielu specjalności medycznych zgłaszają dolegliwości niewyjaśnione przyczynami somatycznymi. Część z nich pilnie poszukuje terapii z powodu dolegliwości „kardiologicznych” (pseudokardiologicznych, pseudosercowych), głównie w postaci przyspieszonego rytmu serca o charakterze psychogennym, niepokojącego odczucia bicia serca niezwiązanego z wysiłkiem (tzw. palpitacji) i bólu zlokalizowanego w klatce piersiowej (także niewynikającego z choroby wieńcowej). W wyniku typowej, w tym nawet bardziej zaawansowanej, diagnostyki serca, zwykle wielokrotnie wnoszącej informację o braku organicznego podłoża tych dolegliwości, pozyskiwanych jest niewiele informacji o stresujących wydarzeniach życiowych i predyspozycjach psychologicznych pacjentów. Ponieważ wielu chorych korzystających z leczenia w formie psychoterapii ma w profilu swoich dolegliwości podobne skargi „pseudokardiologiczne”, wykonywana u nich rutynowo rozległa diagnostyka psychologiczna umożliwia umiejscowienie tych objawów w kontekście sposobu przeżywania i obciążających wydarzeń życiowych. Owa kontekstualizacja dolegliwości może mieć istotne znaczenie nie tylko w takcie leczenia psychiatrycznego, lecz również w ocenie sytuacji zdrowotnej pacjenta dokonywanej przez kardiologa, lekarza podstawowej opieki zdrowotnej czy też innych specjalistów. Stwierdzenie współwystępowania symptomów „sercowych” z innymi objawami typowymi dla zaburzeń nerwicowych ułatwia ustalenie wstępnego rozpoznania już podczas wywiadu.

Cel: Celem pracy było określenie psychospołecznego kontekstu występowania psychogennych „objawów pseudokardiologicznych” oraz ich współwystępowania z innymi objawami u pacjentów z zaburzeniami nerwicowymi.

Metody: Materiał stanowiły historie chorób pacjentów z lat 1980-2002 zawierające kwestionariusze objawowe typu samoopisowego oraz wywiady strukturowane (ankiety życiorysowe) zgromadzone w postaci anonimowej bazy danych. Analizę powiązań między symptomami zgłoszonymi w kwestionariuszu objawowym (odnoszącym się do 7 dni poprzedzających badanie) i okolicznościami biograficznymi opisanymi w ankiecie życiorysowej wypełnianej przez pacjentów przed przyjęciem na dzienny psychoterapeutyczny oddział leczenia zaburzeń nerwicowych przeprowadzono za pomocą jednozmiennych analiz regresji logistycznej prowadzących do oszacowania współczynników ilorazów szans i ich 95\% przedziałów ufności. Do przeprowadzenia obliczeń wykorzystano licencjonowany pakiet oprogramowania statystycznego STATISTICA PL.

Wyniki: Bardzo częste, obecne u większości badanych, objawy tachykardii/palpitacji lub bólu w klatce piersiowej często współwystępowały z innymi objawami nerwicowymi ( $w$ przypadku tachykardii/palpitacji — takimi jak napięcie i duszność, w przypadku bólu w klatce piersiowej — takimi jak duszność i ból mięśni oraz bóle wędrujące), a także ze sobą nawzajem. Objawy pseudokardiologiczne wiązały się też w sposób istotny statystycznie z okolicznościami, takimi jak: nieoptymalne rozwiązywanie konfliktów między pacjentami a ich partnerami — poprzez bierną agresję (powiązaną z bólem w klatce piersiowej zarówno u kobiet, jak i u mężczyzn) lub awantury (powiązane z bólem serca wśród mężczyzn); niepewność w związku (szczególnie u kobiet związaną z bólem serca), poczucie bycia gorszym od partnera, trudna sytuacja materialna (szczególnie u mężczyzn silnie związane z tachykardią/palpitacjami). Ponadto z analizowanymi symptomami pseudokardiologicznymi wiązały się wspominane z dzieciństwa czynniki ryzyka, takie jak pochodzenie z uboższej rodziny wielodzietnej, poczucie gorszości pochodzenia rodzinnego, odczucie wrogości lub braku wsparcia ze strony jednego z rodziców.

Wnioski: Lekarz każdej specjalności mający styczność z pacjentem doznającym dolegliwości typu pseudokardiologicznego powinien spodziewać się ich podłoża psychologicznego i może dokonać sprecyzowania za pomocą względnie prostego wywiadu w kierunku obecności określonych okoliczności biograficznych (trudności w związku, złej sytuacji materialnej lub obciążeń z okresu dzieciństwa). Omówienie z pacjentem trudnych przeżyć może pomóc w nawiązaniu z nim lepszej współpracy, wskutek podjęcia ważnych emocjonalnie tematów, a w efekcie doprowadzić do przekonania pacjenta do zaakceptowania pomocy psychologicznej lub skierowaniu na psychoterapię.

Słowa kluczowe: objawy bez podłoża somatycznego, częste skargi, psychogenny częstoskurcz, psychogenny ból w klatce piersiowej, psychokardiologia

Kardiol Pol 2015; 73, 11: 1114-1121

Adres do korespondencji:

dr n. med. Jerzy A. Sobański, Katedra Psychoterapii, Collegium Medicum, Uniwersytet Jagielloński, ul. Lenartowicza 14, 31-138 Kraków, e-mail: molocko@poczta.fm Praca wpłynęła: 29.01.2015 r.

Zaakceptowana do druku: 24.03.2015 r.

Data publikacji AoP: 14.05.2015 